\title{
Impact of CYP2E1, GSTA1 and GSTP1 gene variants on serum alpha glutathione S-transferase level in patients undergoing anaesthesia
}

Adam Mikstacki ${ }^{1}$, Marzena Skrzypczak-Zielinska², Oliwia Zakerska-Banaszak ${ }^{2,3}$, Barbara Tamowicz ${ }^{1}$ Maria Skibinska ${ }^{4}$, Marta Molinska-Glura ${ }^{5}$, Marlena Szalata ${ }^{6}$ and Ryszard Slomski $i^{2,6^{*}}$

\begin{abstract}
Background: The serum glutathione S-transferase alpha (a-GST) concentration has been used as a marker of hepatic condition. After sevoflurane anaesthesia a mild impairment of hepatocellular integrity was observed. Genetic polymorphisms in CYP2E1, GSTA1 and GSTP1 genes, affecting enzymes activity, may possibly influence the hepatotoxic effect of sevoflurane. The aim of this study was to assess the influence of genetic polymorphism of CYP2E1, GSTA1 and GSTP1 genes on serum a-GST level in 86 unrelated patients representing ASA physical status I-II, undergoing laryngological surgery under general anaesthesia with sevoflurane.

Methods: The serum samples from three perioperative time points were analyzed using ELISA. Genetic variants were detected by pyrosequencing and sequencing. Finally, the statistical associations between serum a-GST concentration and analyzed alleles of CYP2E1, GSTP1 and GSTA1 genes were estimated.

Results: The allele GSTA1*B (-567G, $-69 T$, $-52 \mathrm{~A})$ frequency was 0.43 , whereas the alleles C.313G and c.341T of GSTP1 were identified with frequencies of 0.28 and 0.1 respectively. The $-1053 T$ allele of the CYP2E1 gene was observed with 0.01 frequency. We found serum a-GST concentrations in homozygous changes c.313A>G and c.341C>T of the GSTP1 gene significantly higher at the end of anaesthesia as compared with the levels at pre-anaesthetic and $24 \mathrm{~h}$ post-anaesthetic time points. Moreover, GSTA1 wild type genotype was associated with increased a-GST concentration at $24 \mathrm{~h}$ after the end of anaesthesia.
\end{abstract}

Conclusions: GSTP1 gene polymorphism has an impact on the perioperative serum a-GST concentration in patients undergoing sevoflurane anaesthesia. A similar association, although not statistically significant exists between GSTA1 gene variants and perioperative serum a-GST level.

Keywords: GSTA1, GSTP1, CYP2E1, Polymorphism, a-GST, Hepatotoxicity, Sevoflurane

\section{Background}

The measurement of serum glutathione S-transferase alpha ( $\alpha$-GST) concentration has been used in multiple studies as hepatocellular integrity or renal injury indicator in anaesthetized patients $[1,2]$. It is postulated that liver injury after sevoflurane anaesthesia may occur due

\footnotetext{
* Correspondence: slomski@up.poznan.pl

${ }^{2}$ Institute of Human Genetics, Polish Academy of Sciences, Strzeszynska 32, 60-479 Poznan, Poland

${ }^{6}$ Department of Biochemistry and Biotechnology, University of Life Sciences, Dojazd 11, 60-632 Poznan, Poland

Full list of author information is available at the end of the article
}

to reduction in the liver blood flow caused by inhaled anaesthetic or by the toxic effect of sevoflurane itself or its metabolite [3]. Particularly the fluoromethyl-2, 2difluoro-1-[trifluoromethyl] vinyl ether, a product of sevoflurane breakdown, has been suggested as a deleterious substance [4]. Transient increase of $\alpha$-GST concentration has also been reported after anaesthesia with desflurane, isoflurane, enflurane, halothane and propofol [5-7]. Glutathione S-transferases (GSTs, EC 2.5.1.18) are a superfamily of enzymes responsible for metabolism and the detoxification process of a wide range of 
carcinogens, toxins and drugs including anaesthetic agents by binding them with reduced glutathione [8]. Alpha GST ( $\alpha$-GST, GSTA1) belongs to the most essential class of GST superfamily in the human liver. It is widely used as a more sensitive biomarker of the liver function than conventionally analyzed aspartate aminotransferase (AST) and alanine aminotransferase (ALT) because of its smaller molecular weight and shorter half-life [9]. In hepatocellular impairment, the enzyme is rapidly released from hepatocytes into the bloodstream. Previous studies demonstrate that the enzyme increase may occur directly after the end of sevoflurane anaesthesia, which suggests the toxic influence of the anaesthestic, or after 24 hours, which indicates the toxic effect of metabolites.

Alpha GST is encoded by the polymorphic GSTA1 gene (OMIM 138359). Its different genetic variants are known as altering the enzyme activity in the human liver, which may influence the individual detoxification rate and response to drugs. Therefore, GSTA1 is a subject of intensive molecular research. Expression of GSTA1 depends mainly on two crucial alleles GSTA1*A and GSTA1*B, containing three linked base substitutions located in promoter region: $-567 \mathrm{~T}>\mathrm{G},-69 \mathrm{C}>\mathrm{T},-52 \mathrm{G}>\mathrm{A}$. However, the promoter change in position -52 of the GSTA1 gene impairs the binding process of the Sp1 transcription factor and, in effect, reduces the promoter activity of GSTA1*B by four-fold [10].

The GSTP1 gene (OMIM 134660), which codes for the GSTP1-1 protein of the $\pi$-GST fraction, is widely expressed in most tissues, particularly in the lung, esophagus, and placenta [11]. The variable serum concentration of $\pi$-GST has been used in multiple studies as an indicator of preeclampsia, lung and breast cancer, response to chemotherapy and drug hepatotoxicity [12-14]. Three polymorphic alleles of the GSTP1 gene, GSTP1* $A,{ }^{*} B$ and ${ }^{*} C$, characterized by two amino acid substitutions p.Ile105Val (c.313A $>$ G) and p.Ala114Val (c.341C $>\mathrm{T}$ ) determine the enzyme's activity [15]. Both changes, in codon 105 and 114 are responsible for the enzyme's decreased activity [16], because of their location in the active site of the GSTP1-1 protein.

Sevoflurane, one of the safest and commonly used anaesthetic agent, is metabolized only in $5 \%$ by cytochrome P450, family 2, subfamily E, polypeptide 1 (CYP2E1) encoded by CYP2E1 gene (OMIM 124040), mainly in the liver. Actually 14 CYP2E1 alleles, associated with variable enzyme activity, have been described. Two most relevant variants in the promoter region $-1053 \mathrm{C}>\mathrm{T}$ and $-1293 \mathrm{G}>\mathrm{C}$ are responsible for increased transcription of CYP2E1 [17]. Polymorphism in this gene was intensively investigated in the context of cancer risk and response to drug treatment.
It is presumed that the background of the variability in sevoflurane biotransformation and its possible hepatotoxic effect may constitute the genetic polymorphism of genes coding for metabolizing enzymes [18, 19]. Moreover, until now, there have been no results regarding the genetic background in the safety of sevoflurane anaesthesia. Therefore, the aim of our study was to verify whether an association exists between gene variants CYP2E1 $(-1053 \mathrm{C}>\mathrm{T})$, GSTA1 $(-567 \mathrm{~T}>\mathrm{G},-69 \mathrm{C}>\mathrm{T}$ and $-52 \mathrm{G}>\mathrm{A})$, GSTP1 (c.313A $>\mathrm{G}$ and c.341C>T) and perioperative serum $\alpha-G S T$ concentrations in Polish patients undergoing sevoflurane anaesthesia.

\section{Methods \\ Patients}

A group of 86 unrelated Polish patients (50 males and 36 females) representing ASA physical status I-II, undergoing laryngological surgery under general anaesthesia with sevoflurane, were enrolled in this study. Patients ranged in age from 19 to 75 years old. The body mass index averaged $26.78( \pm 4.67)$. The mean sevoflurane exposition time was $39.15( \pm 23.75)$ min. Exclusion criteria included patients with hepatic disease or abnormal hepatic disfunction, excessive alcohol consumers and cigarette smokers, patients receiving drugs affecting hepatic enzymes.

The study was approved by the local ethics committee of the University of Medical Sciences in Poznan, Poland (Resolution No. 653/09) on 18 June 2009. One day before surgery, patients were informed about the procedure, and all of them gave written consent. Midazolam premedication was administered. For induction, propofol (1 to $2 \mathrm{mg} / \mathrm{kg}$ body mass) and fentanyl ( 1 to $3 \mu \mathrm{g} / \mathrm{kg}$ body mass) were given followed by intravenous administration of vecuronium $(0.1 \mathrm{mg} / \mathrm{kg}$ body mass). Then orotracheal intubation was performed. For maintenance of anaesthesia, the volatile agent sevoflurane (Sevorane; Abbott Laboratories, Abbott Park, Illinois) was used. Ventilation parameters were adjusted so that endtidal carbon dioxide was 30 to $40 \mathrm{mmHg}$ (tidal volume 7 to $10 \mathrm{~mL} / \mathrm{kg}$, and respiratory frequency 12 breaths $/ \mathrm{min}$ ). $1.5 \%$ to $4.0 \%$ sevoflurane was given as 1.5 minimal alveolar concentration (MAC) total fresh gas flow at $1 \mathrm{~L} / \mathrm{min}$ using a vaporizer (model 19.3; Dräger Medical $\mathrm{GmbH}$, Lübeck, Germany) (Low-flow Sevoflurane anesthesia). Systolic, diastolic, and mean arterial pressures, pulse rate, peripheral $\mathrm{O}_{2}$ saturation, and end-tidal gas values were measured before induction of anesthesia and continuously during surgery. The total dose of sevoflurane administered to each patient was calculated in MAC hours. In the termination phase of anesthesia, the vaporizer was turned off 10 to $15 \mathrm{~min}$ before the end of surgery, and low flow was maintained at the rate of $1 \mathrm{~L} / \mathrm{min}$. With the recovery of 
spontaneous ventilation, $100 \% \mathrm{O}_{2}$ at the rate of $5 \mathrm{~L} / \mathrm{min}$ was administered before extubation.

\section{Samples and laboratory analysis}

Blood samples for serum $\alpha$-GST measurement were collected in three time points: directly before induction of anaesthesia $\left(T_{1}\right)$, at the end of anaesthesia $\left(T_{2}\right)$ and $24 \mathrm{~h}$ after the end of anaesthesia $\left(\mathrm{T}_{3}\right)$. The serum was separated and stored at $-20{ }^{\circ} \mathrm{C}$. $\alpha$-GST concentrations were determined with an enzyme-linked immunosorbent assay (ELISA) (GST- $\alpha$ ELISA Kit; Immundiagnostik, Bensheim) according to the standard assay procedure. The absorbance was measured on a plate reader at a wavelength of $450 \mathrm{~nm}$ (Asys UVM 340; Biochrom Ltd, Cambridge, UK). All samples from each patient were analyzed in the same assay run. $\alpha$-GST concentration was quantified against a standard curve. Assays were run in duplicate and the intra-assay variability coefficient was $<5 \%$. The reference of $\alpha$-GST concentration ranged from 0.6 to $20 \mu \mathrm{g} / \mathrm{L}$.

\section{Molecular analysis}

Genomic DNA for molecular analysis was obtained from peripheral blood samples according to standard procedures using the method with guanidine isothiocyanate (GTC). Analysis of GSTA1 promoter variants (in positions -52, -69 and -567) and two substitutions (c.313A $>\mathrm{G}$ and c.341C>T) in GSTP1 gene was performed using sequencing and pyrosequencing respectively, as was described previously [20]. For genotyping of promoter SNP $-1053 \mathrm{C}>\mathrm{T}$ in the CYP2E1 gene we used the pyrosequencing technique. Specific primers (forward 5'-GTGATTTGGCTGGATTGTAAATG-3', reverse 5' CAGACCCTCTTCCACCTTCTATGA-3') for amplification of $239 \mathrm{bp}$-length fragment and sequencing primer (5'-AATTCATAGGTTGCAATT-3') were designed by Pyrosequencing PSQ Assay Design Software. PCR reaction was carried out using Applied Biosystems 2720 Thermal Cycler (Applied Biosystems, Foster City, CA) on the total volume of $30 \mu \mathrm{l}$ containing $0.9 \mathrm{U}$ of FIRE Pol DNA Polymerase ${ }^{\oplus}, 0.2 \mu \mathrm{M}$ of primers, $3.0 \mu \mathrm{l} 10 \mathrm{x}$ buffer, $2.4 \mu \mathrm{l}$ dNTP mix (2.5 mM each dNTP), $1.8 \mathrm{mM}$ $\mathrm{MgCl}_{2}$ solution and $96 \mathrm{ng} \mathrm{DNA}$. The program started with initial denaturation at $95{ }^{\circ} \mathrm{C}$ for $3 \mathrm{~min}$, followed by 50 cycles at $95{ }^{\circ} \mathrm{C}$ for $30 \mathrm{~s}, 60{ }^{\circ} \mathrm{C}$ for $30 \mathrm{~s}$, and $72{ }^{\circ} \mathrm{C}$ for 60 s. All reagents were obtained from Solis BioDyne (Tartu, Estonia). Pyrosequencing was performed by PSQ $^{\mathrm{m}}$ 96MA System (Qiagen) and PyroMark Gold Q96 Reagents (Qiagen GmbH, Hilden, Germany) as described by the manufacturer.

\section{Statistical methods}

For determining the normality of distribution of serum $\alpha$-GST levels, Shapiro-Wilk's normality test was used.
The repeated measures analysis of variance (ANOVA) was applied for evaluation the changes in $\alpha$-GST concentrations between patients at different time points. All calculations were performed using STATISTICA 10.0 software (Stat Soft, 2014). A $p$-value of $<0.05$ was considered statistically significant. The statistical method applied is in line with the experience scheme [21].

\section{Results}

A total of 86 individuals were screened for genetic variants $-52 \mathrm{G}>\mathrm{A} \quad(\mathrm{rs} 3957356), \quad-69 \mathrm{C}>\mathrm{T} \quad$ (rs3957357) and $-567 \mathrm{~T}>\mathrm{G}(\mathrm{rs} 4715332)$ in the GSTA1 gene promoter region, two substitutions c.313A $>\mathrm{G}$ and c.341C $>\mathrm{T}$ in GSTP1 gene and the promoter change $-1053 \mathrm{C}>\mathrm{T}$ in CYP2E1 gene. The allele GSTA1*B (-52A, -69T, -567G) frequency was 0.43 (while each allele combination frequencies were 0.34 for $A^{*} / A^{*}, 0.46$ for $A * / B *$ and 0.20 for the $\left.\mathrm{B}^{*} / \mathrm{B}^{*}\right)$. Allele c.313G of GSTP1 gene produced frequency of 0.28 (genotype $\mathrm{A} / \mathrm{A}$ were observed with 0.52 frequency, genotypes $\mathrm{A} / \mathrm{G}$ and $\mathrm{G} / \mathrm{G}$ with 0.38 and 0.1 frequency respectively). Whereas allele c.341T of GSTP1 gene was detected with 0.1 frequency (genotype $\mathrm{C} / \mathrm{C}$ with $0.84, \mathrm{C} / \mathrm{T}$ with 0.13 and $\mathrm{T} / \mathrm{T}$ with 0.03 frequency were observed). The CYP2E1-1053T allele had 0.01 frequency.

In the whole study group we have measured serum $\alpha$-GST concentration in three perioperative time points. We observed the individual and interindividual differences in enzyme concentration levels. The increase in $\alpha$-GST level (minimum of $20 \%$ compared to a basal value T1) in $39.5 \%$ of patients at the end of anaesthesia $\left(\mathrm{T}_{2}\right)$ and in $27.9 \%$ of subjects at $24 \mathrm{~h}$ after the end of anaesthesia $\left(\mathrm{T}_{3}\right)$ was observed. The perioperative changes in $\alpha$-GST concentration are illustrated in (Fig. 1). In individuals with GSTP1 c.313G/G genotype the early postoperative serum $\alpha$ GST concentration was significantly higher, compared with the preanaesthetic and $24 \mathrm{~h}$ postanaesthetic measurements. Changes in $\alpha$-GST concentrations between patients were evaluated at different time points using repeated measures analysis of variance where $p=$ 0.00004 (Fig. 2). Similarly, patients carrying GSTP1 c.341TT genotype demonstrated significantly higher $\alpha$-GST concentration when compared with basal and $24 \mathrm{~h}$ postanaesthetic values using the same test ( $p=$ 0.0000) (Fig. 3). Moreover, we found wild type homozygotes of GSTA1 $(-52 \mathrm{C} / \mathrm{C},-69 \mathrm{G} / \mathrm{G},-567 \mathrm{~A} / \mathrm{A})$ as associated, but not statistically significantly, with increased $\alpha$-GST concentration at $24 \mathrm{~h}$ after the end of anaesthesia, when compared with the preoperative and early postoperative values (Fig. 4). The promoter change $-1053 \mathrm{C}>\mathrm{T}$ in $C Y P 2 E 1$ gene had no impact on the enzyme profile during the analyzed perioperative time in patients anaesthetized with sevoflurane. 


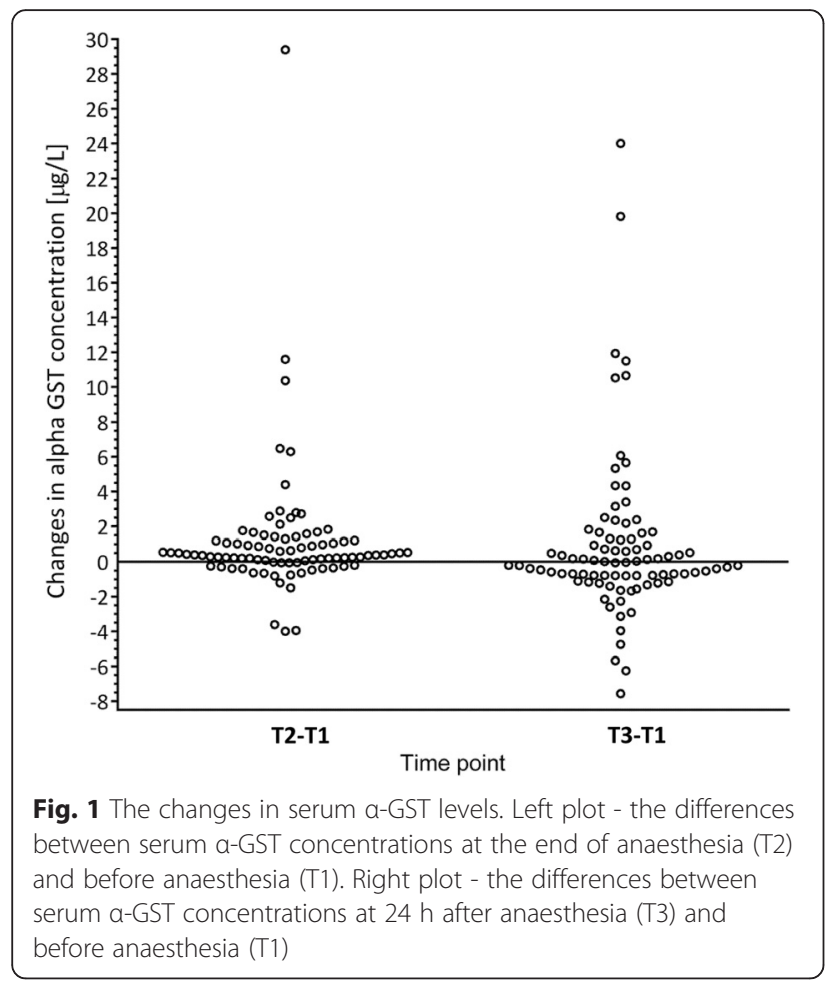

\section{Discussion}

Human GST was indicated in numerous studies as a sensitive marker of hepatocellular impairment [9, 22]. The enzyme is released from the hepatocytes into the bloodstream if hepatocellular integrity is disrupted. Measurements of serum $\alpha$-GST concentration have been used many times in studies analyzing the influence of anaesthetics on hepatocellular integrity. Up to now, the results regarding sevolfurane have suggested mild impairment, but the background of this effect is not clear. Ray et al. [3] has demonstrated the significant increase in GST at $1 \mathrm{~h}$ after the end of sevoflurane infusion, compared with baseline level (before anaesthesia). He also observed that some patients exhibit an increased GST level at $24 \mathrm{~h}$ after the end of anaesthetic infusion. Studies conducted by Taivainen et al. [7] indicated that general anesthesia with sevoflurane and halothane administered to children resulted in the increase in $\alpha$-GST concentration in the serum, which returned to normal within $24 \mathrm{~h}$. Similarly, Suttner et al. [2] observed minimally affected hepatic integrity after desflurane and sevoflurane anaesthesia in elderly patients. Studies performed on a group of patients anaesthetized with sevoflurane showed that after $1 \mathrm{~h}$, serum $\alpha$-GST level increased in both groups [1]. Kaymak et al. [23] also has proved the early postoperative increase in serum $\alpha$-GST in patients after sevoflurane anaesthesia.

Our study has also demonstrated that sevoflurane anaesthesia resulted in a transient early postoperative increase in serum $\alpha$-GST concentration. Generally, the observed enzyme growth was mild, with the exception of individuals carrying GSTP1 c.313G/G, or c.341 T/T genotype, where the enzyme rise was statistically significant when compared with preanaesthetic and $24 \mathrm{~h}$ postanaesthetic level. Elevated enzyme concentrations mostly returned to the baseline within $24 \mathrm{~h}$. However, $\alpha-G S T$ concentrations were still elevated at $24 \mathrm{~h}$ after anaesthesia in wild type homozygotes GSTA1 $-52 \mathrm{C} / \mathrm{C},-69 \mathrm{G} / \mathrm{G},-567 \mathrm{~A} / \mathrm{A}$.

The first trials to correlate the variability of GST enzyme concentration with the genetic polymorphism were

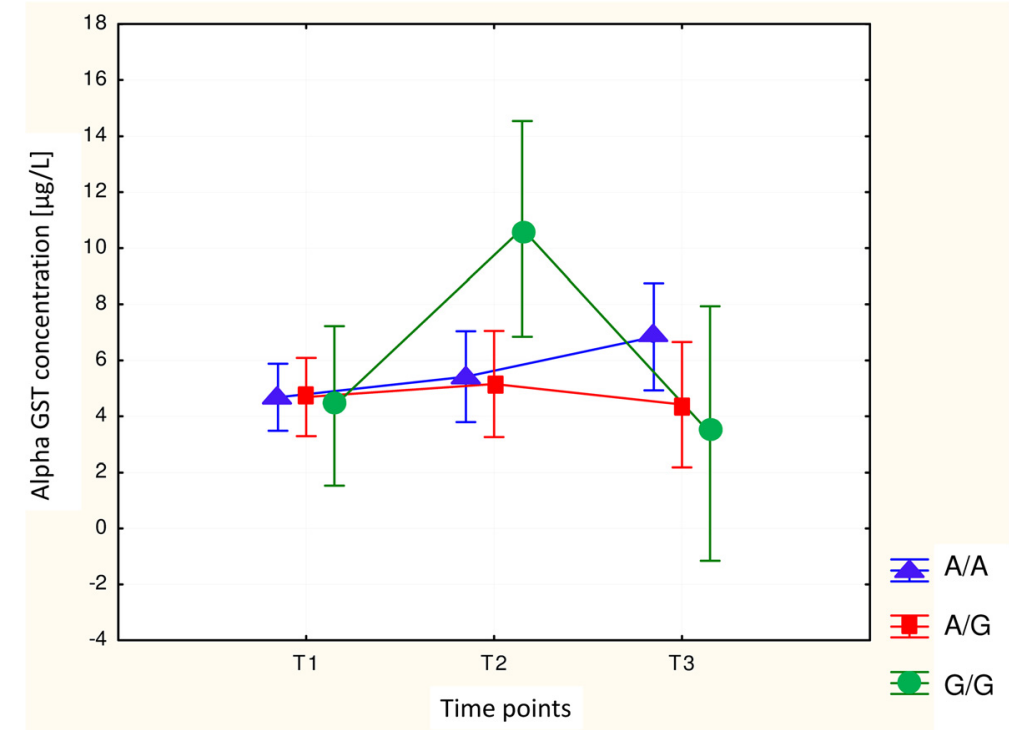

Fig. 2 Perioperative changes in the serum a-GST level depending on genotype A/A, A/G, G/G at position 105 of the GSTP1 gene 


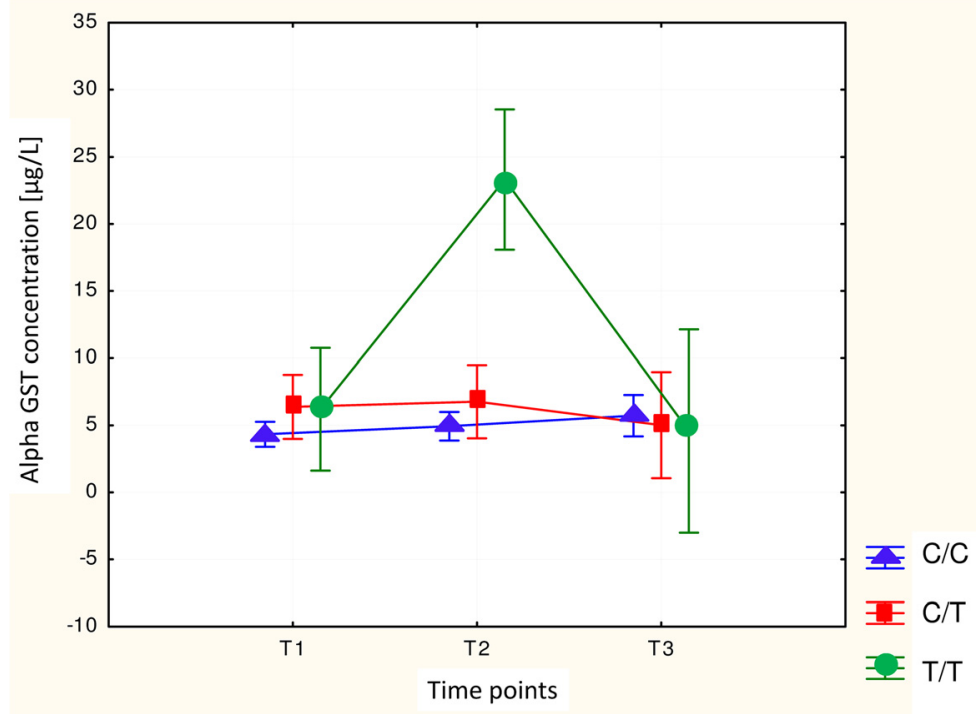

Fig. 3 Perioperative changes in the serum a-GST level depending on genotype $C / C, C / T, T / T$ at position 114 of the GSTP1 gene

performed by Kaymak et al. [23]. He confirmed that GSTP1 heterozygote c.313A/G had significantly higher serum $\alpha$-GST concentrations at $24 \mathrm{~h}$ compared with the wild type genotype. Our study has not confirmed these results. Although we have also tested the influence of p.Ile105Val change on the enzyme level, it seemed more likely that there would be an association between polymorphism in the GSTA1 or CYP2E1 gene and enzyme level, because GSTA1 gene is responsible for synthesis of the $\alpha$-GST protein, and CYP2E1 gene codes the main enzyme involved in sevoflurane biotransformation.
In our study, all selected polymorphisms cause altered enzyme activity: CYP2E1 $(-1053 \mathrm{C}>\mathrm{T})$ increases it, and GSTA1 $(-567 \mathrm{~T}>\mathrm{G}, \quad-69 \mathrm{C}>\mathrm{T}, \quad-52 \mathrm{G}>\mathrm{A})$ and GSTP1 (c.313A $>$ G, c.341C $>\mathrm{T})$ changes reduce it $[10,16,17]$. These alleles are described in the literature as strongly associated with the variable efficiency of metabolism and detoxification of numerous compounds, as well as with drug therapy and susceptibility to diseases. Any changes in the sevoflurane biotransformation rate (both in metabolism and in the detoxification process) may pose a risk of hepatotoxic effect of sevoflurane [18].

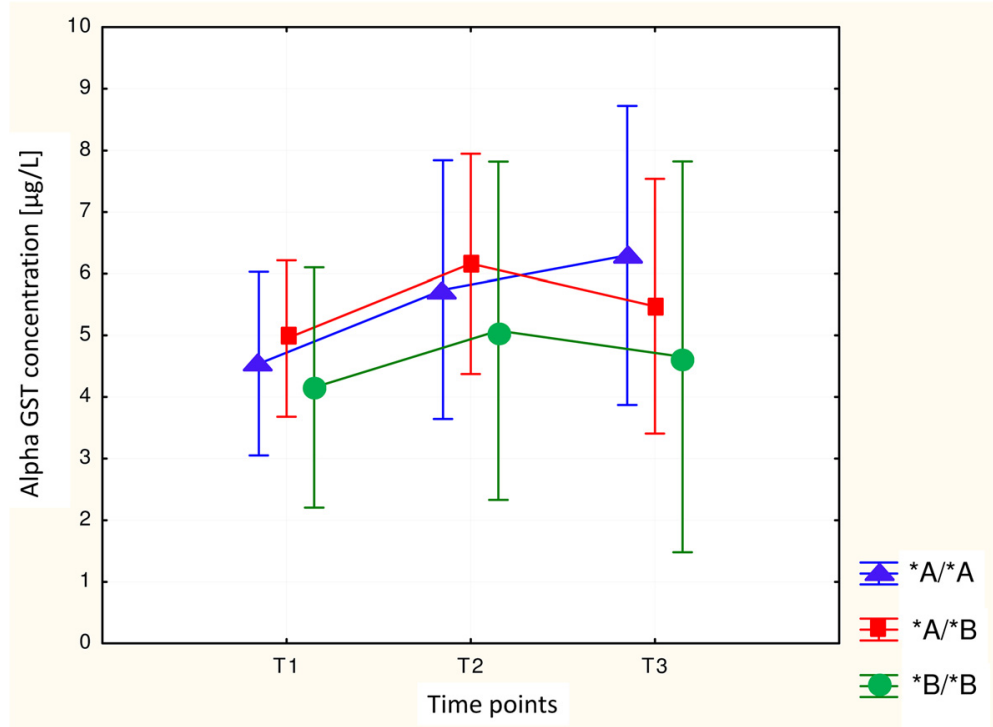

Fig. 4 Perioperative changes in the serum a-GST level depending on alleles ${ }^{*} A{ }^{*} A,{ }^{*} A /{ }^{*} B$ and ${ }^{*} B /{ }^{*} B$ of the GSTA1 gene 
The increase in $\alpha$-GST concentration at the early postoperative time point may be explained by the evidence suggesting that sevoflurane reduces total hepatic blood flow in humans [24]. There is no clear suggestion of a hepatotoxic metabolite of sevoflurane, which might initiate the damage of hepatocytes.

In our study two polymorphisms in GSTP1 gene (p.I105V and p.A114V) proved to be relevant to the transient hepatocellular impairment in patients after sevoflurane anaesthesia. Although the polymorphism at codon 105 of GSTP1 gene was also found to be crucial in the study by Kaymak et al. [23], the effect on the change in enzyme level is different in our study.

\section{Conclusions}

The present study is a preliminary work and further analyses on larger populations and longer infusion times are needed. However, in summary, we can conclude that GSTP1 p.I105V and p.A114V variants have an impact on the increased serum $\alpha$-GST concentration in patients undergoing sevoflurane anaesthesia. A similar association, although not statistically significant exists between GSTA1 gene variants and perioperative serum $\alpha$-GST level.

\author{
Abbreviations \\ a-GST: Serum glutathione S-transferase alpha; ANOVA: Analysis of variance; \\ ALT: Alanine aminotransferase; AST: Aspartate aminotransferase; \\ CYP2E1: Cytochrome P450, family 2, subfamily E, polypeptide 1; \\ ELISA: Enzyme-linked immunosorbent assay; MAC: Minimal alveolar \\ concentration.
}

\section{Competing interests}

The authors declare that they have no competing interests.

\section{Authors' contribution}

AM: participated in study concept and design, obtaining of funding, organization of medical part of research, critical revision of the manuscript for important intellectual connect. MS-Z: participated in study concept and design, acquisition of molecular genetics data, analysis and interpretation of data, participated in draft preparation of manuscript. OZ-B: carried out molecular genetics analysis and interpreted obtained data, prepared draft of manuscript. BT: acquisition and interpretation of medical data, critical revision of the manuscript, participated in draft preparation of manuscript. MS: carried out the enzyme immunoassay. MM-G: performed the statistical analysis. MSz - participated in acquisition of molecular genetics data, analysis and interpretation of data. RS: participated in study concept and supervision, critical revision of the manuscript for important intellectual connect. All authors read and approved the final manuscript.

\section{Acknowledgements}

This work was supported by the Polish Ministry of Science and Higher Education (grant no. Polish Ministry of Science and Higher Education) and the Foundation for the Development of Biotechnology and Genetics POLBIOGEN. Oliwia Zakerska-Banaszak holds a scholarship from The European Regional Development Found - ERDF and European Fund for Innovative Economy and Foundation for Polish Science. She also holds a scholarship within the project "Scholarship support for Ph.D. students specializing in majors strategic for Wielkopolska's development", Sub-measure 8.2.2 Human Capital Operational Programme, co-financed by European Union under the European Social Fund. We thank Prof. Idzi Siatkowski and Katarzyna Gorczak for stimulating discussions.

\section{Author details}

'Department of Anaesthesiology and Intensive Therapy, Regional Hospital, Juraszow 7/19, 60-479 Poznan, Poland. ${ }^{2}$ Institute of Human Genetics, Polish Academy of Sciences, Strzeszynska 32, 60-479 Poznan, Poland. ${ }^{3}$ The NanoBioMedical Centre, Adam Mickiewicz University, Umultowska 85, 61-614 Poznan, Poland. ${ }^{4}$ Department of Genetics in Psychiatry, University of Medical Sciences, Szpitalna 27/33, 60-572 Poznan, Poland. ${ }^{5}$ Department of Computer Science and Statistics, University of Medical Sciences, Dabrowskiego 79, 60-529 Poznan, Poland. ${ }^{6}$ Department of Biochemistry and Biotechnology, University of Life Sciences, Dojazd 11, 60-632 Poznan, Poland.

Received: 3 September 2015 Accepted: 7 May 2016

Published online: 14 May 2016

\section{References}

1. Yousif MA, Khafagy HF, El-Shanawani FM, El-Sabae HH, Omar SH, Allam MN, et al. Hepatocellular integrity during sevoflurane anesthesia with induced hypotension. J Egypt Soc Parasitol. 2009:39:641-51.

2. Suttner SW, Schmidt CC, Boldt J, Hüttner I, Kumle B, Piper SN. Low-flow desflurane and sevoflurane anesthesia minimally affect hepatic integrity and function in elderly patients. Anesth Analg. 2000;91:206-12.

3. Ray DC, Bomont R, Mizushima A, Kugimiya T, Howie AF, Beckett GJ. Effect of sevoflurane anaesthesia on plasma concentrations of glutathione Stransferase. Br J Anaesth. 1996:77:404-7.

4. Goldberg ME, Cantillo J, Gratz I, Deal E, Vekeman D, McDougall R, et al. Dose of compound $A$, not sevoflurane, determines changes in the biochemical markers of renal injury in healthy volunteers. Anesth Analg. 1999:88:437-45.

5. Tiainen P, Lindgren L, Rosenberg PH. Changes in hepatocellular integrity during and after desflurane or isoflurane anaesthesia in patients undergoing breast surgery. Br J Anaesth. 1998;80:87-9.

6. Arslan M, Kurtipek O, Dogan AT, Unal Y, Kizil Y, Nurlu N, et al. Comparison of effects of anaesthesia with desflurane and enflurane on liver function. Singapore Med J. 2009;50:73

7. Taivainen T, Tiainen P, Meretoja OA, Räihä L, Rosenberg PH. Comparison of the effects of sevoflurane and halothane on the quality of anaesthesia and serum glutathione transferase alpha and fluoride in paediatric patients. Br J Anaesth. 1994;73:590-5.

8. Hayes JD, Pulford DJ. The glutathione S-transferase supergene family: regulation of GST and the contribution of the isoenzymes to cancer chemoprotection and drug resistance. Crit Rev Biochem Mol Biol. 1995; 30:445-600.

9. Koo DJ, Zhou M, Chaudry IH, Wang P. Plasma alpha-glutathione S-transferase: a sensitive indicator of hepatocellular damage during polymicrobial sepsis. Arch Surg. 2000;135:198-203.

10. Morel F, Rauch C, Coles B, Le Ferrec E, Guillouzo A. The human glutathione transferase alpha locus: genomic organization of the gene cluster and functional characterization of the genetic polymorphism in the hGSTA1 promoter. Pharmacogenetics. 2002;12:277-86.

11. Moscow JA, Fairchild CR, Madden MJ, Ransom DT, Wieand HS, O'Brien EE, et al. Expression of anionic glutathione-S-transferase and P-glycoprotein genes in human tissues and tumors. Cancer Res. 1989:49:1422-8.

12. Eger 2nd El, Koblin DD, Bowland T, lonescu P, Laster MJ, Fang Z, et al. Nephrotoxicity of sevoflurane versus desflurane anesthesia in volunteers. Anesth Analg. 1997;84:160-8.

13. Watson MA, Stewart RK, Smith GB, Massey TE, Bell DA. Human glutathione S-transferase P1 polymorphisms: relationship to lung tissue enzyme activity and population frequency distribution. Carcinogenesis. 1998;19:275-80.

14. Canto P, Canto-Cetina T, Juárez-Velázquez R, Rosas-Vargas H, RangelVillalobos $\mathrm{H}$, Canizales-Quinteros S, et al. Methylenetetrahydrofolate reductase C677T and glutathione S-transferase P1 A313G are associated with a reduced risk of preeclampsia in Maya-Mestizo women. Hypertens Res. 2008:31:1015-9.

15. Board PG, Webb GC, Coggan M. Isolation of a CDNA clone and localization of the human glutathione $\mathrm{S}$-transferase 3 genes to chromosome bands 11 q13 and 12q13-14. Ann Hum Genet. 1989;53:205-13.

16. Harries LW, Stubbins MJ, Forman D, Howard GC, Wolf CR. Identification of genetic polymorphisms at the glutathione S-transferase Pi locus and association with susceptibility to bladder, testicular and prostate cancer. Carcinogenesis. 1997;18:641-4. 
17. Ingelman-Sundberg M. Polymorphism of cytochrome P450 and xenobiotic toxicity. Toxicology. 2002;181-182:447-52.

18. Restrepo JG, Garcia-Martin E, Martinez C, Agundez JAG. Polymorphic drug metabolism in anaesthesia. Curr Drug Met. 2009;10:236-46.

19. Mikstacki A, Skrzypczak-Zielinska M, Tamowicz B, Zakerska-Banaszak O, Szalata M, Slomski R. The impact of genetic factors on response to anaesthetics. Adv Med Sci. 2013;58:9-14.

20. Skrzypczak-Zielinska M, Zakerska-Banaszak O, Tamowicz B, Sobieraj I, Drweska-Matelska N, Szalata M, et al. Polymorphisms and allele frequencies of Glutathione S-transferases A1 and P1 genes in the Polish population. Genomics Mol Res. 2015;14:2850-9.

21. Rosner B. Fundamentals of Biostatistics. Brooks/Cole Cengage Learning: Boston, USA; 2010

22. Mikstacki A, Zakerska-Banaszak O, Skrzypczak-Zielinska M, Tamowicz B, Szalata M, Slomski R. Glutathione S-transferase as a toxicity indicator in general anesthesia: genetics and biochemical function. J Clin Anesth. 2015;27:73-9.

23. Kaymak C, Karahalil B, Ozcan NN, Oztuna D. Association between GSTP1 gene polymorphism and serum alpha-GST concentrations undergoing sevoflurane anaesthesia. Eur J Anaesthesiol. 2008;25:193-9.

24. Hongo T. Sevoflurane reduced but isoflurane maintained hepatic blood flow during anesthesia in man. J Anesth. 1994:8:55-9.

Submit your next manuscript to BioMed Central and we will help you at every step:

- We accept pre-submission inquiries

- Our selector tool helps you to find the most relevant journal

- We provide round the clock customer support

- Convenient online submission

- Thorough peer review

- Inclusion in PubMed and all major indexing services

- Maximum visibility for your research

Submit your manuscript at www.biomedcentral.com/submit
Biomed Central 